\title{
SELECTED BIOCHEMICAL BLOOD PLASMA PARAMETERS OF MALE NUTRIAS DURING POSTNATAL ONTOGENESIS
}

\author{
P. JELINEK and J. ILLEK
}

Department of Cattle, Horse and Sheep Husbandry, Faculty of Agronomy, University of Agriculture, 66265 Brno and

Department of Diagnosis, Therapy and Control of Animal Diseases, University of Veterinary Science, 61242 Brno

\begin{abstract}
J e 1 i n e k P., J. I 11 e k: Selected Biochemical Blood Plasma Parameters of Male Nutrias During Postnatal Ontogenesis. Acta. vet.Brno, 56,1987:41-52.

Selected biochemical parameters of blood plasma (total protein, fraction of albumins, alpha globulin, beta and gamma globulins, urea content, activity of alkaline phosphatase, AST and ALT, concentrations of glucose, calcium, magnesium, inorganic phosphorus, copper and manganese) of male nutrias of standard breed are presented. The animals were allocated to 10 age groups from 1 to 300 days of age. The results obtained in individual age categories were mathematico-statistically evaluated.
\end{abstract}

Nutria, blood, protein, urea, glucose, AST, ALT, minerals.

When evaluating the effect of external environment on the organism the knowledge of basic hematological and biochemical data of blood finds its application. This is particularly true for young growing animals. The significance of these laboratory analyses increases.with ever growing load on animal organism due to a number of factors among which the non-traditional technologies, intensity of exploatation, way of nutrition, use of new genotypes and different experimental interventions are the most serious ones.

Although several papers have been published concerning hematology of the nutria, information on biochemical blood values of these animals is very scarce (K r c h ̌̃ a v ý 1977; B u 1 e c a 1981; J e 1 i n e k et al. 1982; We n z e 1 1982; K o m á r e k 1983). Apart from insufficient knowledge the fact that data concerning physiological values of nutria blood were obtained mostly from blood collected from nasal cavities on killing the animals is another reason lowering the utility of such results. These samples lack altogether essential categorization of the investigated material from the viewpoint of age, sex, season, etc.

Owing to the mentioned shortage of information on biochemical blood values of nutrias we have used for the evaluation and comparison of our results the findings obtained on other animal species and published e.g. by A n k e (1964), K o n r ád (1971), U n d e r wo o d (1971), A n k e (1972), Ko $1 \mathrm{~b}$ and $\mathrm{G} \ddot{\mathrm{u}} \mathrm{t} 1 \mathrm{e} \mathrm{r}$ (1971), S t r e 1 c o va (1972), 
Surynek et al. (1975), I 11 e k (1979), J a go š et al. (1980), J a go s and B o u d a (1981), J a go ś et al. (1981), J e 1 ine $k$ et al. (1983), J e 1 i n e $k$ et al. (1984).

The present work has been devoted to the determination of selected values of the metabolic profile of male nutria blood plasma. The animals were of standard breed and the investigation was carried out during their postnatal ontogenesis, from birth to breeding age.

\section{Materials and Methods}

Male nutrias of the standard breed, from two farms where breeding conditions were known to us and were on a good level, were used in the study. In both cases the animals were housed in brick cages with water reservoirs. Feeding was traditional with summer feed ration (clover-grass mixture, soaked barley and wheat, irregularly waste bread).

The age of animals ranged from 1 to 300 days. The whole period of investigation was divided into 10 time intervals representing the distribution of the total number of animals into the following age groups: $1,15,30,60$, $90,100-105,115-130,150,180-210$, and 240 - 300 days. Each age group was represented by different number of individuals, their minimal number being not less than 7 in one group. The blood samples were taken by heart puncture into heparinized test tubes between noon and $5.00 \mathrm{p} . \mathrm{m}$. The blood plasma was obtained within 30 minutes after the blood sampling.

The following parameters were determined from these blood plasma samples: total protein using the Bio-Test (Lachema), fraction of albumins, alpha globulin and also of gamma + beta globulin by electrophoresis. The evaluation was carried out on an automatic densitometer Densiscan. Activities of alkaline phosphatase, AST, ALT, and urea and inorganic phosphorus concentrations were determined photometrically using the Bio- Test sets (Lachema). The content of $\mathrm{Ca}, \mathrm{Mg}$ and $\mathrm{Cu}$ was determined by atomic absorption spectrophotometry AAS on the Hilger Atomspek instrument. For the calibration the standard solutions for AAS produced by Harleco were used. The $\mathrm{Mn}$ concentration was measured by the flameless atomic absorption spectrophotometry on the Atomspek H 1551 instrument equipped by an automatic deuterium background corrector. The measurement was effected directly without applying the integration.

\section{Results}

Postnatal development of biochemical parameters of blood plasma showing also the mean standard deviations is presented in Fig. 1 - 8 .

The level of total protein (Fig. 1) during the postnatal development ranged from 54.95 to $62.81 \mathrm{~g} / 1$. The values within this range did not exceed the limits of statistical significance $(F<P=0.05)$. Also within individual groups the variability level was found to be mostly low to medium ( $v=$ $4.93-14.16 \%$ ).

The albumin fraction (Fig. 1) decreased gradually, in spite of slight fluctuation during ontogenesis, from the initial values of $40.70 \mathrm{~g} / 1$ in one day old animals to the lowest value of $31.87 \mathrm{~g} / 1$ at the age of 150 days, the average content in adult individual being $33.17 \mathrm{~g} / 1$. The broad span of average values is reflected also by the results of variance analysis. The level of coefficients of variance showed mean values.

The fraction of alpha globulins showed after birth $(4.92 \mathrm{~g} / \mathrm{l})$ an in- 


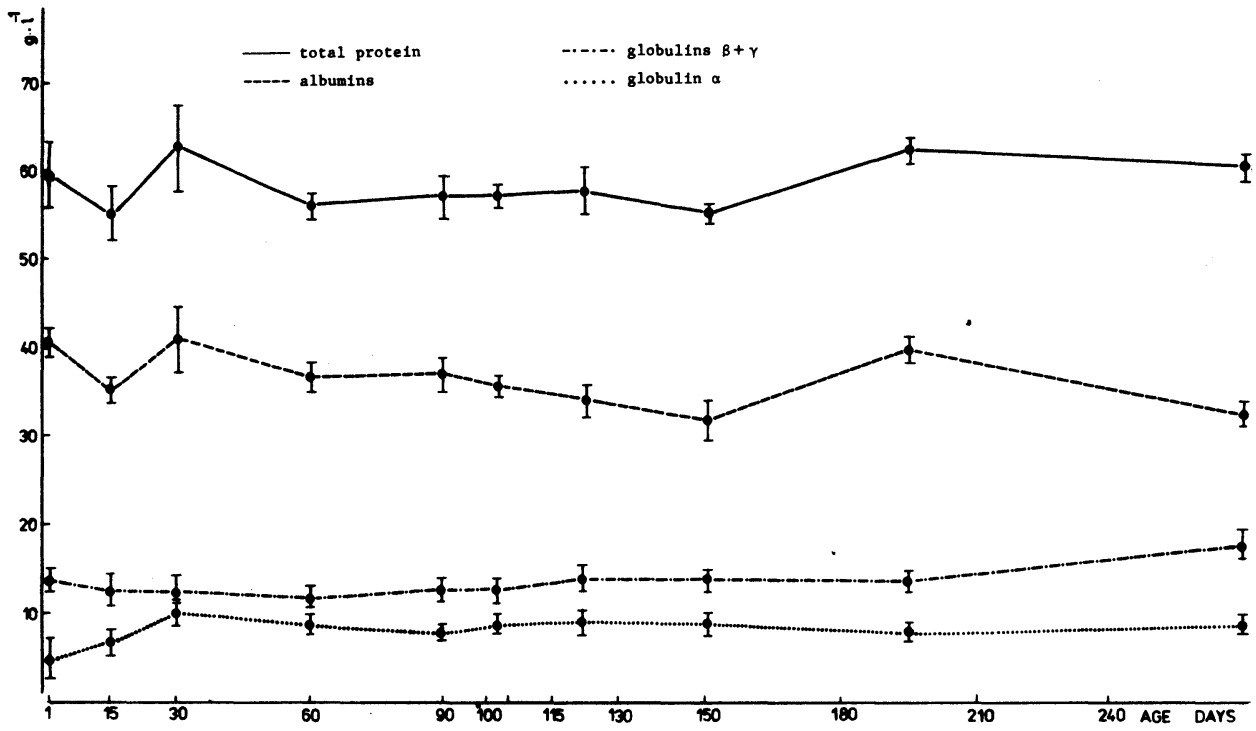

Fig. 1. Total protein, albumins, alpha globulins and beta + gamma globulins in the blood plasma of nutrias aged 1 to $300 \mathrm{~d}$.

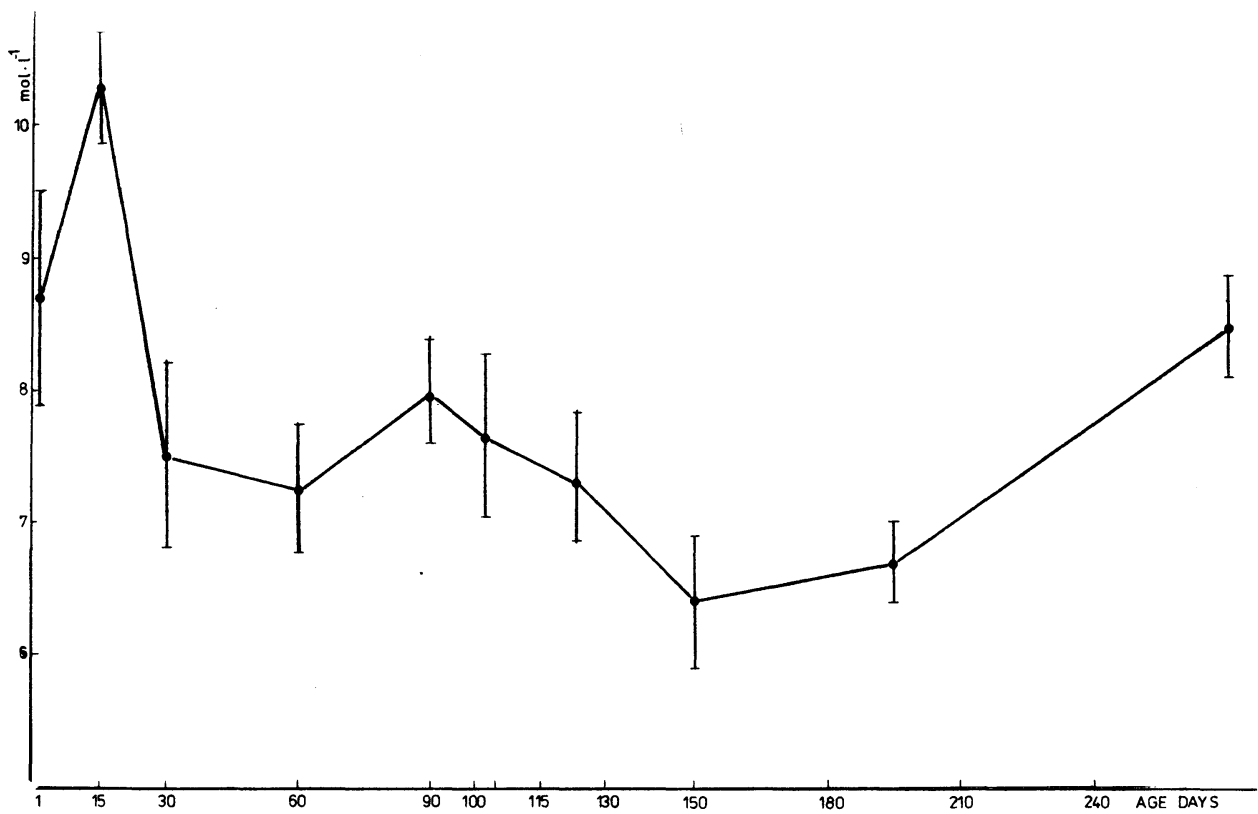

Fig. 2. Urea content in the blood plasma of nutrias aged 1 to $300 \mathrm{~d}$. 


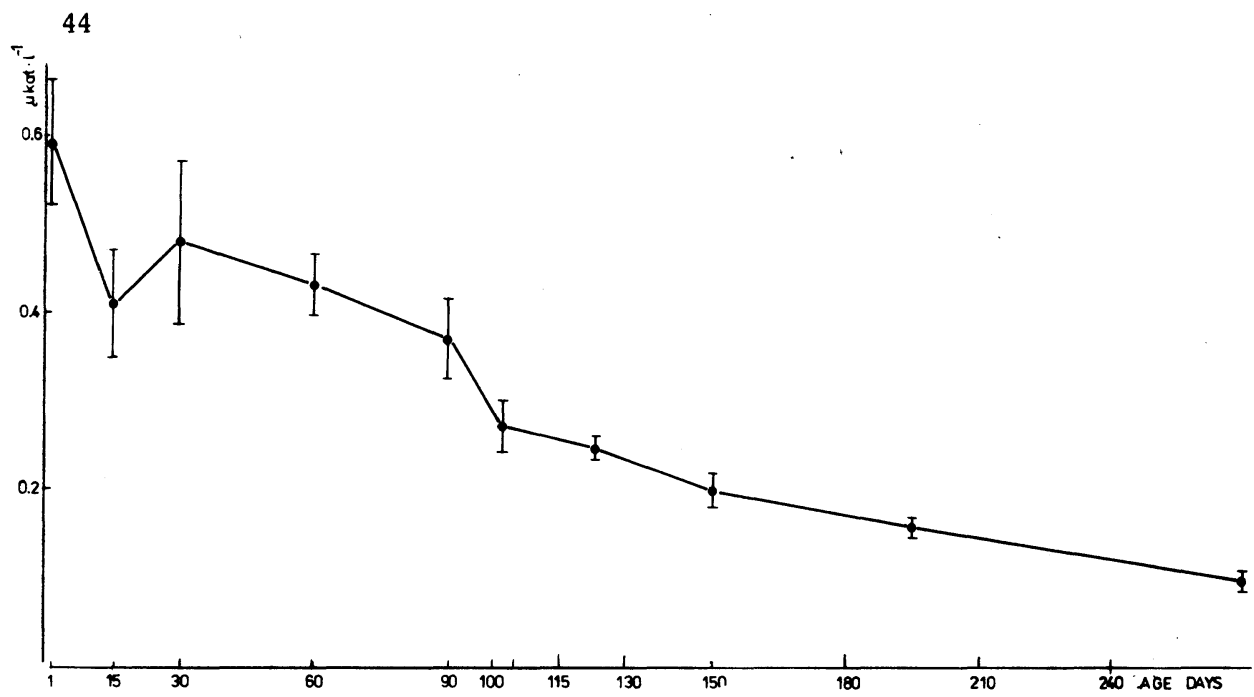

F1g. 3. Alkaline phosphatase values in the blood plasma of nutrias aged 1 to $300 \mathrm{~d}$.

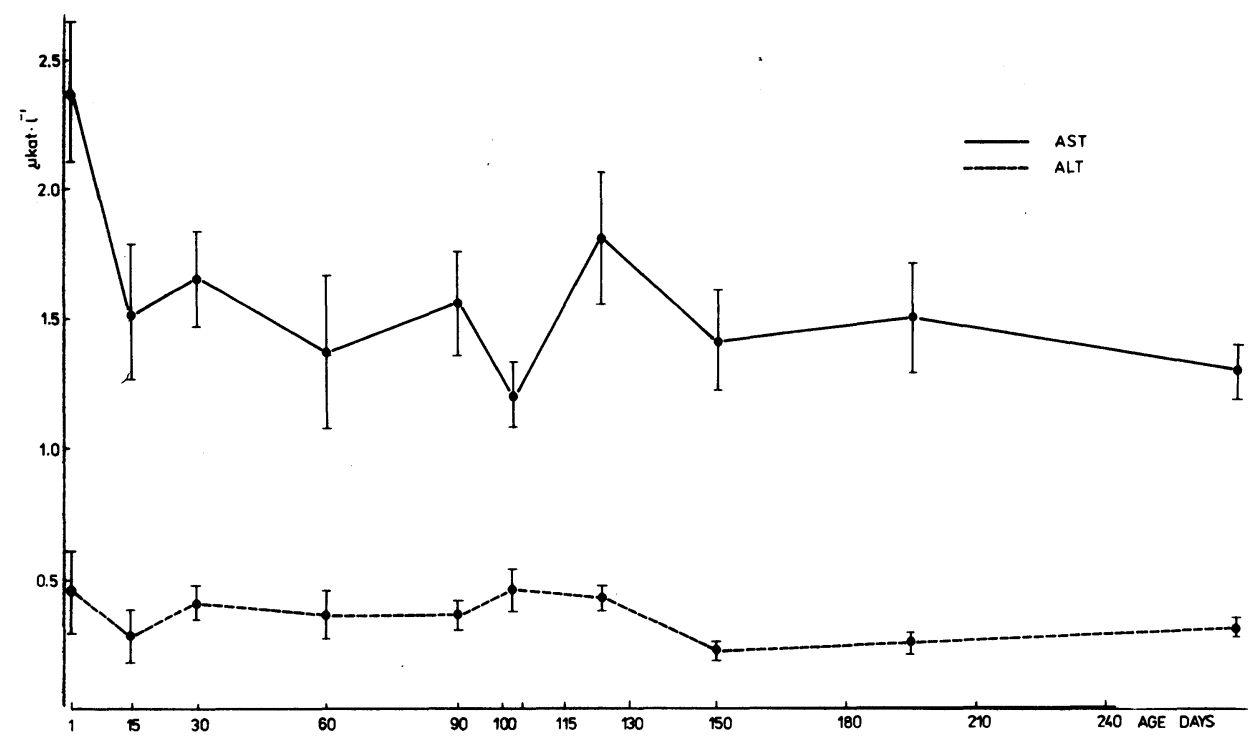

Fig. 4. AST and ALT values in the blood plasma of nutrias aged 1 to $300 \mathrm{~d}$. 
creasing tendency up to the age of 30 days when their concentration doubled; in the remaining time period of investigation a slight decrease in the proportion of this component was followed by stabilization with a final mean value of $9.10 \mathrm{~g} / 1$ (Fig. 1). Statistically significant difference was found among individual age groups in most cases. The values of coefficients of variance ranged from $\mathrm{v}=19.60$ to $53.7 \%$.

The fraction of beta + gamma globulins gradually increased during the postnatal development from $13.84 \mathrm{~g} / 1$ (age 1 day) to $18.26 \mathrm{~g} / 1$ (age 240 300 days). Small differences among individual groups are corroborated also by the results of their testing, statistical difference being found only between the following age groups: 60 and $115-130$ days, 150 and $180-210$ days, 150 and 240 - 300 days. The span of coefficients of variation was found to be $10.85-35.29 \%$.

The urea content in the blood plasma varied within the range of mean values from $6.82 \mathrm{mmol} / 1$ (age 115 - 130 days) to $10.27 \mathrm{mmol} / 1$ (age 15 days) (Fig. 2). Statistically significant and highly statistically significant differences were found between the youngest and oldest age groups. Within groups mainly medium to high variability $\left(v^{\prime}=13.52-41.37 \%\right)$ was found.

The alkaline phosphatase activity showed a decreasing tendency during the postnatal development, the highest mean value of $0.594 \mu \mathrm{kat} / \mathrm{l}$ being determined in one-day old nutrias whereas the lowest level $(0.101 \mu \mathrm{kat} / 1)$ was found in adult animals (Fig. 3). This tendency was supported also by a highly significant relationship between the alkaline phosphatase activity and the age of nutrias with the calculated $r=-0.705^{++}$. Higher individual differences are reflected also in a higher level of variability $(v=12.56-$ $52.51 \mathrm{8}$ ). Also the analysis of variance showed that the tested difference reached the limits of statistical significance at the beginning of postnatal development and in older animals.

The development of mean values of aspartate aminotransferase (AST) activity is illustrated in Fig. 4. Variation in activities during the development showed on the whole a decreasing tendency, limited by the age of one day and by a mean AST level of $2.363 \mu \mathrm{kat} / 1$ and by the last category of adult animals with the mean level of $1.300 \mu \mathrm{kat} / \mathrm{l}$. The values of coefficients of variations exceeded $20 \%$.

The activity of alanine aminotransferase (ALT), similarly as in the case of AST, showed relatively high individual differences although these differences among age groups were found to be within limits of non-significance $(F<P=0.05)$. The span of mean values was found to range from $0.225 \mu \mathrm{kat} / 1$ (age 150 days) to $0.448 \mu \mathrm{kat} / 1$ (age 1 day), see Fig. 4 .

The glucose concentration exhibited from birth to the age of $115-130$ days a varying level, in further periods of breeding its level, however, markedly stabilized (Fig. 5). Its mean concentration in individual age groups was limited by values of $6.31 \mathrm{mmol} / 1$ (age 1 day) and $8.39 \mathrm{mmol} / 1$ (age 30 days). Statistically significant or highly significant differences were found predominantly in the relationship between the glucose content in the 30-day age category and other age categories. A relationship on the border of statistical significance $(r=-0.284)$ was observed between the plasma glucose concentration and the age of animals.

The concentration of calcium ranged from $2.33 \mathrm{mmol} / 1(115-130$ days of age) to $2.79 \mathrm{mmol} / \mathrm{l}$ (age 150 days). Higher variability of calcium concentrations was found in younger age categories of male nutrias (Fig. 6) which is supported by statistically significant differences among several age groups. The values of coefficients of variation varied about $10 \%$.

Somewhat higher differences were observed in the concentration of magnesium (Fig. 6) where the mean values during investigation ranged 


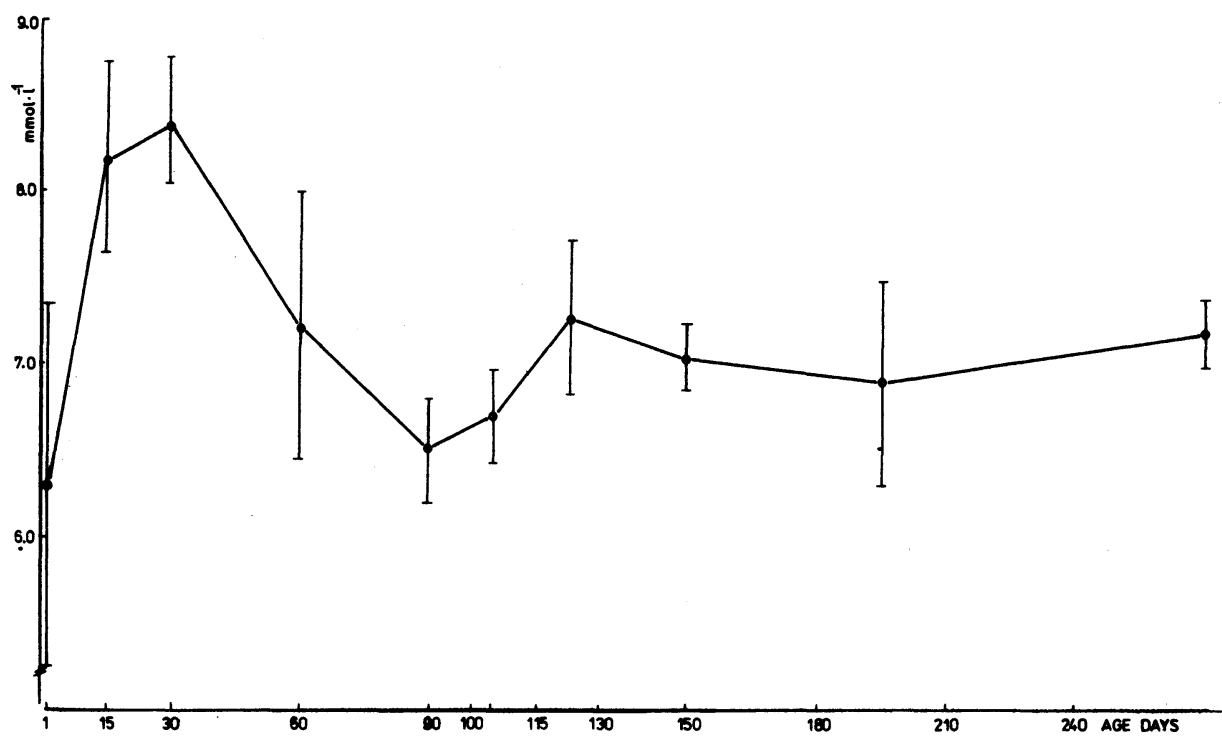

Fig. 5. Glucose content in the blood plasma of nutrias aged 1 to $300 \mathrm{~d}$.

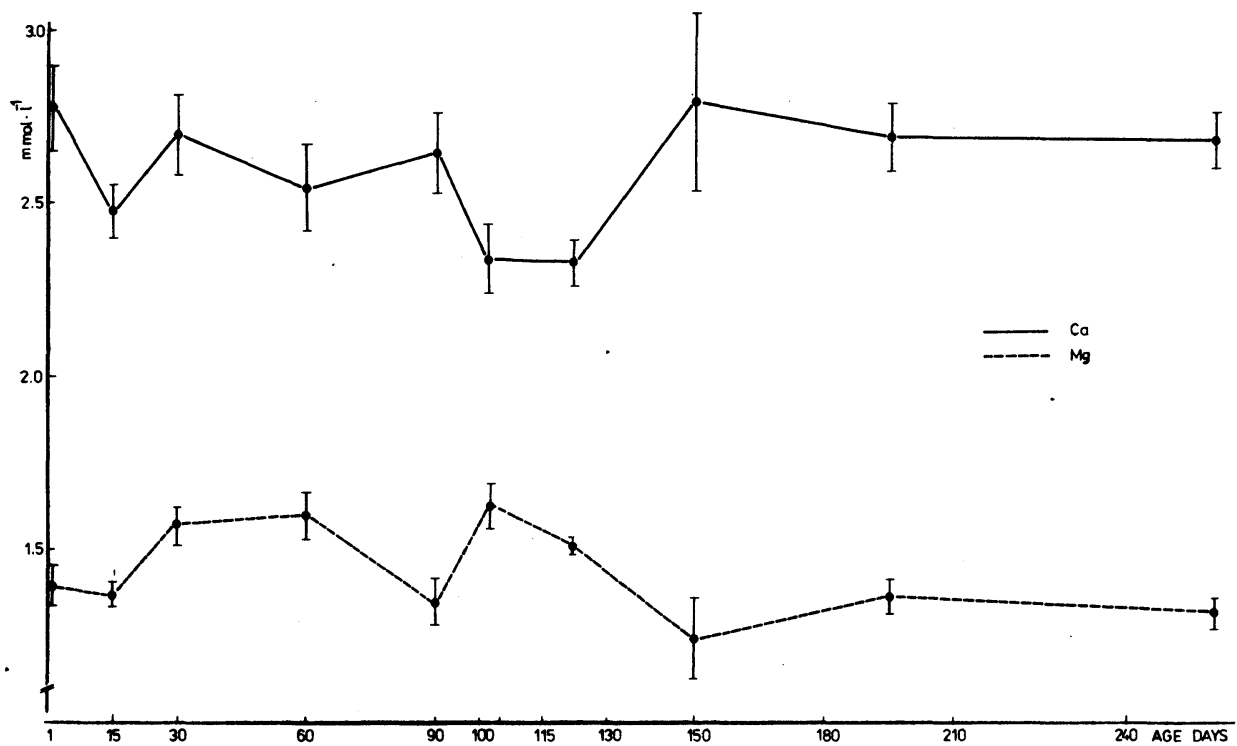

Fig. 6. Calcium and magnesium content in the blood plasma of nutrias aged 1 to $300 \mathrm{~d}$. 
between $1.25 \mathrm{mmol} / 1$ (age 150 days) and $1.63 \mathrm{mmol} / 1$ (age 100 - 105 days). The level of variability assessed by the coefficient of variability varied from 4.7 to 22.408 .

The content of inorganic phosphorus was found to range from 2.41 mmol/l to $2.78 \mathrm{mmol} / 1$, the differences between mean levels in individual time-gaps found by simple analysis of variance being statistically inconclusive (Fig. 7).

The concentration of copper during the investigation ranged from 12.6 $\mu \mathrm{mol} / 1$ (age 15 days) to $22.90 \mathrm{jmol} / 1$ (age 150 days) (Fig. 8), the variability within individual groups being high. No statistically significant differences in the plasma copper concentration were found between groups $(F<P=$ 0.05).

The concentration of manganese showed a stable level during the whole postnatal period ( 1 - 300 days), the mean values varying within the range of $0.39 \mu \mathrm{mol} / 1$ and $0.55 \mu \mathrm{mol} / 1$ (Fig. 8). As in the precening microelement, the differences did not reach over the limit of statistical significance.

\section{Discussion}

Within a selected time interval the concentration of total protein during the postnatal development exhibited altogether a balanced level which is supported also both by the assessment of statistical significance between individual age categories and by the values of calculated coefficients of variation. The obtained concentration of total protein in nutrias was found

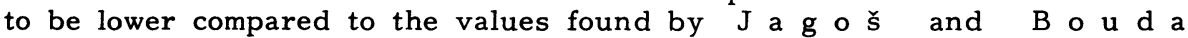
(1981) for cattle, pigs and horses. They correspond to the data presented by $\mathrm{K} \circ \mathrm{m}$ a $\mathrm{r}$ e $\mathrm{k}$ (1983) who reports the mean content of $61.73 \mathrm{~g} / 1$ for adult nutrias regardless of sex and age and also with the findings of $\mathrm{J}$ ag o s et al. (1980) and of J e lí n e k et al. (1983) obtained on growing lambs. Slightly higher concentration of total protein in the blood plasma has also been found when compared with the data obtained for rabbits, physiological values of which were determined by K o n r á d (1971).

Albumin fractions showed a decreasing tendency during the postnatal development and corresponded in average to the findings of $K \circ n \quad r$ a $d$ (1971) in rabbits. The average value of $35.4 \mathrm{~g} / 1$ obtained by $\mathrm{K}$ o $\mathrm{m}$ a $\mathbf{r}$ e $\mathrm{k}$ (1983) in adult nutrias was found approximately in the middle of the span observed by us. The proportion of the remaining protein fractions can be assessed similarly.

The concentration of urea, one of the main final products of protein metabolism, varied in the blood plasma from $6.82 \mathrm{mmol} / 1$ to $10.27 \mathrm{mmol} / 1$, exhibiting a decreasing tendency during the ontogenesis. The values found are slightly higher compared to those of other mammals. They are, however, comparable with the values determined by us in sheep ( $\mathrm{J}$ e 1 í $\mathrm{n}$ e $k$ et al. 1984) and with the results published by $J$ a $g$ o s et al. (1980) on lambs. On the other hand, if compared with the data observed by $\mathrm{K}$ o $\mathrm{m}$ a$r$ e $k$ (1983) who found the average value of $6.33 \mathrm{mmol} / 1$ for adult nutrias, the urea concentration was determined to be higher $(7,97 \mathrm{mmol} / 1)$ in the corresponding age category of 240 - 300 days. It is generally reported that the urea concentration in blood plasma is dependent on the level of protein nutrition and that it is influenced by the functional condition of liver and kidneys ( $\mathrm{J}$ a $\mathrm{g}$ o š et al. 1981). As reported by $\mathrm{V} \mathbf{r} \mathbf{z} \mathbf{g}$ u l a (1982) and $\mathrm{J}$ e $\mathrm{l}$ i $\mathrm{n} \mathrm{e} \mathrm{k}$ et al. (1983) the dynamics of urea content in blood could be employed for the evaluation of the nitrogen nutrition level. 


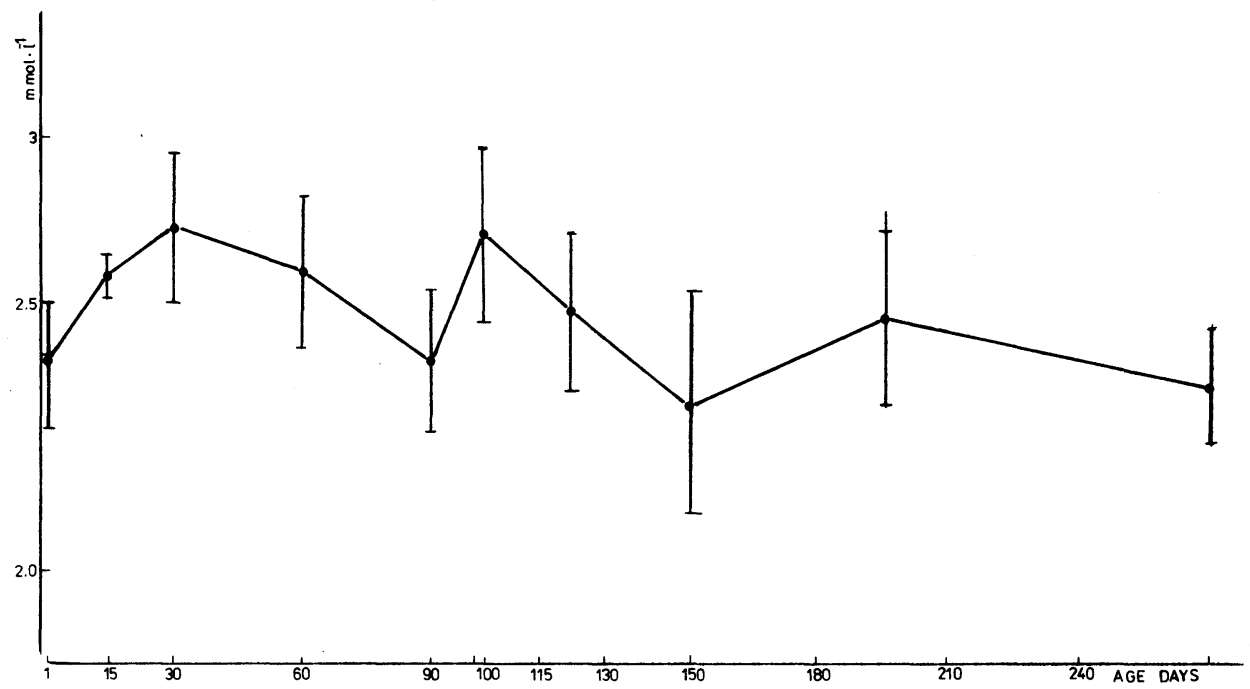

F1g. 7. Inorganic phosphorus content in the blood plasma of nutrias aged 1 to $300 \mathrm{~d}$.

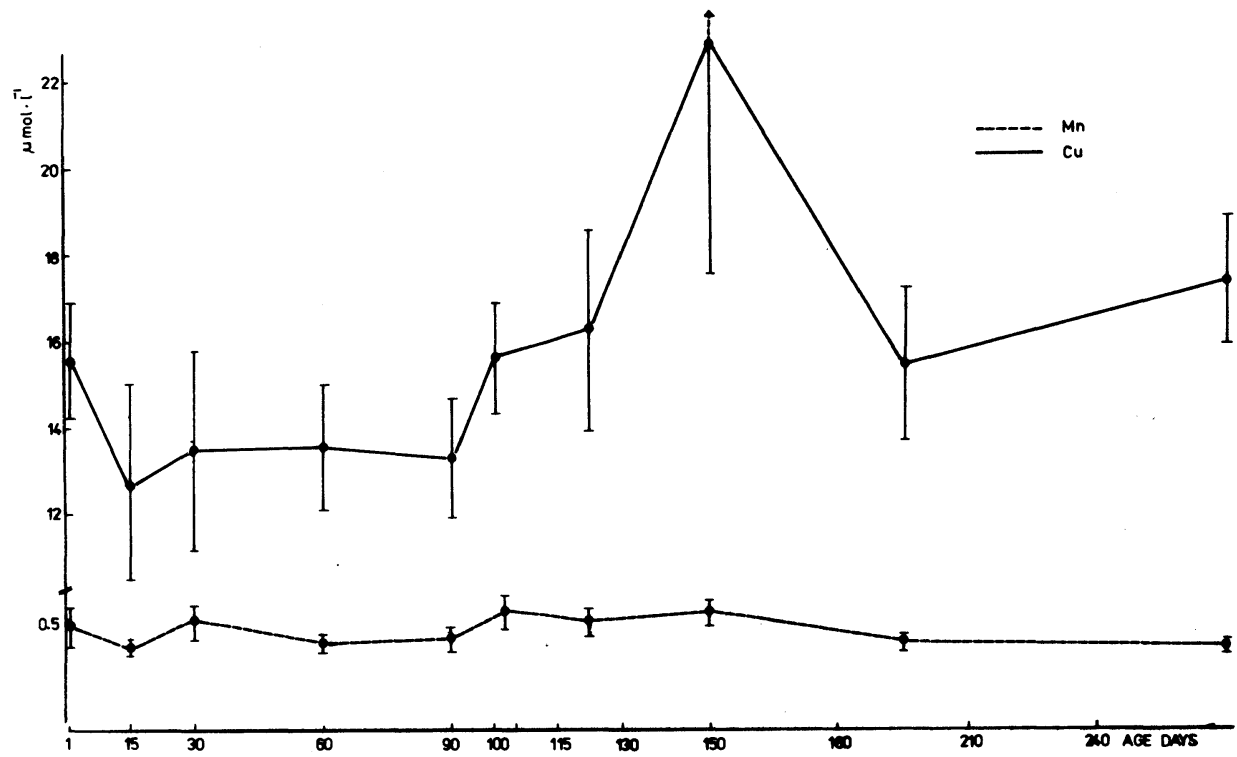

Fig. 8. Copper and manganese content in the blood plasma of nutrias aged 1 to $300 \mathrm{~d}$. 
The activity of alkaline phosphatase gradually decreased with the increasing age of male nutrias and a negative, highly significant relationship $\left(r-0.705^{++}\right)$was found between the alkaline phosphatase activity amd age. This finding only corroborates the data published by $H \circ F$ e $\mathrm{s}_{\mathrm{i}}$ et al. (1963). According to these authors the higher values in young animals may be accounted for by the growth and mineralization of bones. Similar trend is described by $S$ u y $\mathrm{n}$ e $k$ et al. (1975) for early postnatal phase in calves. The alkaline phosphatase activities measured in nutrias are in average lower than those found in cattle and pigs, being nevertheless very similar to those of sheep, dogs and rabbits ( $J$ a $g$ o $s$ 1980).

Very high activity was observed in the case of aspartate aminotransferase in the blood of one-day old nutrias. Although in other phases of ontogenesis the level of activity was lower the found value exceeded those observed in other domestic animals ( $\mathrm{J}$ a $\mathrm{g} \circ \mathrm{s}$ and $\mathrm{B} \circ \mathrm{u} \mathrm{d}$ a 1981). Also the comparison with the findings of $\mathrm{B}$ u $1 \mathrm{e} \mathrm{c}$ a (1981) and $\mathrm{K}$ o $\mathrm{m}$ a $\mathrm{e}$ (1983) indicates that our values are higher. Aspartate aminotransferase is an enzyme which is contained in high concentrations in cells of liver and strained muscles. Its activity increases in degenerative process, intensive body mass wasting or excessive physical load ( $\mathrm{J}$ a $\mathrm{g} \circ \mathrm{s}$ et al. 1981). The extent to which the presented factors could influence the experimental material cannot be unequivocally established.

The values of alanine aminotransferase in the nutria blood plasma ranged from $0.225 \mu \mathrm{kat} / 1$ to $0.448 \mu \mathrm{kat} / 1$ and correspond to basic values published by $\mathrm{S} \circ \mathrm{v}$ a et al. (1976) and by $\mathrm{J}$ a $\mathrm{g} \circ \mathrm{s}$ and $\mathrm{B}$ o $\mathrm{u} \mathrm{d}$ a (1981) for common species of farm animals. K $\circ \mathrm{m}$ á $\mathbf{r}$ e $k$ (1983) however a lower alanine aminotransferase activity in the blood of adult nutrias.

Compared with other animals species the plasma glucose level in male nutrias was found to be higher, the average values ranging from 6.31 to $8.39 \mathrm{mmol} / 1$. B u 1 e c a (1981) and K o m á r e k (1983) report a lower level of this parameter in adult nutrias. The observation of $W$ e n$z$ e 1 (1982), who found a mean glucose concentration of 6.92 and 5.58 mmol/1 in male and female nutrias, resp. in the category of corresponding age, is however in accordance with our finding. It cannot be excluded that the observed higher glucose concentrations were induced by stress of animals being captured and manipulated during sample taking.

The calcium content caried from $2.32 \mathrm{mmol} / 1$ to $2.79 \mathrm{mmol} / 1$ which is the span altogether corresponding to the reference values in other animals ( $S \circ \mathrm{v}$ a 1979; J a $\mathrm{g} \circ \mathrm{s}$ et al. 1980; J a g $\mathrm{s}$ and $\mathrm{B} \circ \mathrm{u} \mathrm{d}$ a 1981). Similar results for adult nutrias were published by $K \circ \mathrm{m}$ á $\mathrm{r} k$ (1983) who found the value of $2.51 \mathrm{mmol} / 1$. K $\mathrm{r}$ c h $\overline{\mathrm{n}} \mathrm{a} \dot{\mathrm{y}}$ (1977) reports the value of $3.3 \mathrm{mmol} / 1$ of blood plasma for the same category.

Magnesium being mostly an intercellular cation, is present in a small amount in blood plasma. The found range of mean values from $1.25 \mathrm{mmol} / \mathrm{l}$ to $1.74 \mathrm{mmol} / 1$ corresponds to the concentrations observed by $\mathrm{K}$ c h $\overline{\mathrm{n}}$ a$v \dot{y}$ (1977) $1.23 \mathrm{mmol} / 1$ and by $\mathrm{K}$ o m á $\mathrm{r}$ e $\mathrm{k}$ (1983) $1.46 \mathrm{mmol} / 1$. The concentrations of magnesium in the blood plasma of nutrias were found to be higher as compared to other animal species.

The concentration of inorganic phosphorus during the postnatal ontogenesis decreased in spite of various variations and its level in the last age group $(2.44 \mathrm{mmol} / 1)$ corresponds to the value of $2.32 \mathrm{mmol} / 1$ reported by $K r c h \bar{n}$ a $v \dot{y}$ (1977) and to that of $2.40 \mathrm{mmol} / 1$ reported by $K \circ \mathrm{m} a \mathrm{r}$ e $\mathrm{k}$ (1983). This tendency is in accordance with the data published by $J$ e $l$ i $n$ e $k$ et al. (1983) on growing rams. Due to the fact that the content of inorganic phosphorus changes in dependence on 
its intake, on the level of mineralization and demineralization processes in bones and on age ( $\mathrm{t}$ e $1 \mathrm{c} \circ \mathrm{v}$ a 1972; $\mathrm{J}$ a $\mathrm{g}$ o s et al. 1981) the presented factors may have influenced the inorganic phosphorus content in the blood plasma of studied nutrias.

The concentration of copper varied from $12.67 \mu \mathrm{mol} / 1$ to $22.89 \mu \mathrm{mol} / 1$. The higher value of this range corresponds to the average content determined for adult male nutrias by $K r$ h $\bar{n}^{\prime}$ a $v \dot{y}$ (1977). The copper content in blood plasma is markedly influenced by the level of copper in food. It decreases rapidly with deficiency of copper in nutrition, this fact being exploited in diagnosis of copper deficiences and metabolic disturbances ( $111 \mathrm{e} \mathrm{k}$ 1979). The copper deficiency adversely affects the pigment formation, hair growth and reproduction (A $n k e$ 1964; $W$ e $n$ e 1 1974). The plasma copper concentrations of the nutrias studied fit within the range regarded as reference values for cattle ( I 1 1 e $k$ 1979) and for reared rams ( $\mathrm{e} 1 \mathrm{i} \mathrm{n}$ e $k$ et al. 1983). They are however lower when compared with the copper concentrations found in pigs ( $\mathrm{J}$ a $\mathrm{g} \circ \mathrm{s}$ et al. 1981).

Manganese has been studied lately mainly in connection with bone metabolism and reproductive processes. The manganese content found in growing nutrias is low, within the range from $0.39 \mu \mathrm{mol} / 1$ to $0.55 \mu \mathrm{mol} / 1$ and corresponds to the values determined in other animal species ( $K \circ 1 \mathrm{~b}$

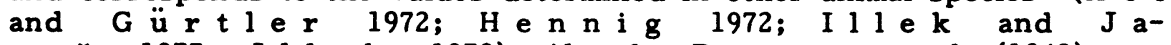
g o s 1977; I 11 e k 1979). Already B o y e $r$ et al. (1942), $\mathrm{S} \mathrm{m}$ i t h (1944 - in: U n d e r w o o d 1971) reported on the occurrence of sterility and lack of libido in male rats and rabbits suffering from manganese deficiency. Also $W$ e $n$ e 1 (1974) describes marked reproduction disturbances in carnivorous fur animals of both sexes when the intake of manganese in feed ration is not adequate. The occurrence of fertility disturbances in some of our nutria farms and inadequate libido of male nutrias require a more detailed study also from the viewpoint of mangenese deficiency.

\section{Vybrané biochemické ukazatele krve samců nutrí $v$ postnatální ontogenezi}

U 90 samců nutrif plemene standard ve věku $1,15,30,60,90,100$ $105,115-130,150,180-210$ a $240-300$ dnu byly stanoveny vybrané biochemické hodnoty krevní plazmy. Prưměrná koncentrace celkové bílkoviny se pohybovala $v$ rozmezí $55,0-62,8 \mathrm{~g} / 1$, albuminú $31,9-41,1 \mathrm{~g} / 1$, globulinů alfa $4,9-10,1 \mathrm{~g} / 1$, globulinů beta a gama $12,6-18,3 \mathrm{~g} / 1$, moČoviny $6,4-10,3 \mathrm{mmol} / 1$. alkalické fosfatázy $0,10-0,59 \mu \mathrm{kat} / 1$, aspartátaminotransferázy (AST) $0,52-2,36 \mu$ kat/1; alaninaminotransferázy (ALT) $0,23-0,45 \mu \mathrm{kat} / 1$, glukózy 6,3 - 8,4 mmol/1, vápníku $2,3-2,8 \mathrm{mmol} / 1$, hoř Cíku $1,3-1,6 \mathrm{mmol} / 1$, fosforu $2,4-2,8 \mathrm{mmol} / 1$, mědi $12,7-22,9 \mu \mathrm{mol} / 1$ a manganu $0,4-0,6 \mu \mathrm{mol} / 1$.

Динамика избранных биоцхимических показателей крови самцев нутрий в период постнатального онтогенеза

у 90 самцев нутрий породы стандарт в возрасте 1, 15, 30 , $60,90,100-105,115-130,150,180-210$ и $240-300$ суток определяли избранные биоцхимические величины хровяной плазмы. Средняя концентрация общих белков достигала пределов 55,0 62,8 г/л, альбуминов $31,9-41,4$ г/л, глобулинов альфа 4,9 - 


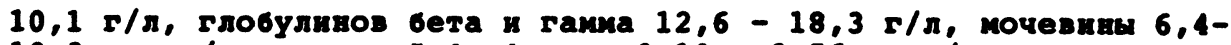
10,3 моль/л, велочво фосфатазы 0,10 - 0,56 мкат/ $\pi$, аспартатаминотравсферазы (АСТ) 0,52 - 2,36 мххат/, , алавивамивотравсферазы (АЛТ) 0,23 - 0,45 иккат/л, глюкозы $6,3-8,4$ ммоль/л, хальция $2,3-2,8$ моль/л, магвия $1,3-1,6$ моль/л, фосфора $2,4-2,8$ моль/л, меди 12,7 - 22,9 мкмоль/л и мангана 0,4 0,6 ихмоль/л.

\section{References}

ANRE, M.: Der Mengen und Spurenelemengehalt des Rinderhaares als Indikator der Calcium, Magnesium, Phosphor, Kallum, Natrium, Elsen, Zink, Mangan, Kupfer, Molybden und Kobalt Versorgung. Jena Untv. 1964, $177 \mathrm{p}$.

ANKE, M.: Kupfermangelbedingte Störungen bel Schafen und Rindern. Monatsch. f. Vet. Med. 28,1972 : 294-299.

BOYER, P.D. - SHAW, J.H. - PHILlIPS, P.H.: J. B101. Chem. 143, 1942, 417. In: Underwood: Trace Elements in Human and Animal Nutrition 1977.

BULECA, J.: Štúdium blologických vlastností nutrifi, Myocastor coypus M. 1782. PhD. Thes18, Košice, VŠv, 1981; 165 p.

HENNIG, A.: Mineralst offe, Vitamine, Ergotropika. Berlin, VEB Deutsch. Landwirtschaftsverlag, 1972, 558 p.

HOREJŠ1, J. et al.: Základy kinetické biochemle ve vnitřním lékařství. Praha, SZN, 1963, 576 p.

ILLEK, J.: Problematika diagnostiky karencí manganu, mědi a zinku. Ph.D. Thesis, Brno, vŠ, 1979, 111 p.

JAGOS, P.: Základní biochemické a hematologické hodnoty u domácích zvířat a nové zpưsoby vyjadřování výsledků laboratorních vyšetření. Veterinárni péče ve velkochovech skotu, Odděleni veterinární osvěty, Pardubice, 1980.

JAGOS, P. - BOUDA, J.: Základní biochemické a hematologické hodnoty u domácích zvirrat a nové způsoby vyjadřování výsledků laboratorních vyšetření. Oddělení veterinární osvěty, Pardubice, 1981, $30 \mathrm{p}$.

JAGOS, P. - ILLEK, J. - ZYKA, V.: Systém preventivní diagnostiky metabolických a produkčních chorob $v$ chovech prasnic. SVS, oddělení veterinárni osvěty, Pardubice, 1981, $26 \mathrm{p}$.

JAGOS, P. et al.: Studium poruch minerálního metabolismu u'ovcí. Project report, Brno, University of Vet.Sc1., 1980, $72 \mathrm{p}$.

JAGOS, P. et al.: Vypracování systému preventivní diagnostiky poruch výměny látkové u skotu.*iroject report, Brno, University of Vet. Sci., 1981,37 p.

JELINEK, P. - ILLEK, J. - JAGOS, P.: Obsah zinku, manganu a mědı v krevní plazmě, srsti, gonádách a přidatných pohlavních žlázách nutrí. Żiv. výr., Praha 27, 1982: 223-232.

JELINEK, P. - ILLEK, J. - HELANOVA, I. - FRAIS, Z.: Základní charakteristika vnitřního prostředí beránků $v$ průběhu odchovu. In: Šlechtitelské a moderni metody testace $v$ chovu ovcí. C. Budějovice, vŠz, 1983: 86-98.

JELINEK, P. - FRAIS, Z. - HELANOVÃ, I.: Základní hematologické hodnoty beranů $v$ průběhu odchovu. Acta univ. agric. (Brno), fac. agron., 31 , 1984: 117-125.

KOMARER, J.: Některé biochemické a hematologické hodnoty krve nutrie. Vet. Med. Praha, 28, 1983: 351-354. 
KONRíD, J.: Nenoci králíkủ. Praha, SPN, 1971, 290 p.

RRCHIXVY, J.: Stanovente zákiadných biochenických ukazatelov, makro- a mikroprvkov u klinicky zdravých nutril. Studentská vědecká práce, Brno, 1977, 5 p.

SOVA, Z.: Soustava SI jednotek a její používání v Żivočižné výrobè a veterinární nedicínè. VŠz Praha, 1979, 20 p.

SOVA, Z. - KOLIANDR, 0. - JICHA, J.: Základni fyziologické hodnoty v krvi ovcí. Sborník vysoké školy zemědělské v Praze, fakulta agronomická, Yada B, 1976: 57-71.

STRELCOVA, N.L.: Dinamika belkovo-mineralnogo obmena 1 nekotorych klinikofiziologiCeskich pokazatelej pro eksperimentalnom gipo- 1 gipertireoze u ovec. Avtoref. kand. diss., Vitebsk 1982, 17 p.

SURYNEK, J. - KUCERA, A. - JANÓ, J. - HOJOVCOVA, M.: Výzkum enzymatických poruch př́ trávení u telat. Sledování některých základních ukazatelủ biomedicínského profilu telete v postnatálnim obodbí. Project report VO. Brno, VŠv $1975,65 \mathrm{p}$.

UNDERWOOD, E.J.: Trace element in human and animal nutrition. Academic Press, New York and London, 1971, $543 \mathrm{p}$.

VRZGULA, L. et al.: Poruchy látkového metabolismu hospodárskych zvierat a Ich prevencta. Príroda, Bratislava, 1982, $492 \mathrm{p}$.

WENZEL, D.: Edelpelztiere. Berlin, VEB Deutscher Landwirtschaftsverlag, 1974, $558 \mathrm{p}$.

WENZEL, U.D.: Pelztiergesundheitsdienst. Jena, VEB Gustav Fischer Verlag, 1982, 254 p. 